\title{
Szociológiai paradigmák és a biográfiakutatás ${ }^{1}$
}

\author{
Bögre Zsuzsanna \\ bogre.zsuzsanna@btk.ppke.hu \\ https://doi.org/10.51624/SzocSzemle.2020.4.4 \\ Beérkezés: 2020. 03. 19. \\ Átdolgozott változat beérkezése: 2020. 11. 03. \\ Elfogadás: 2021. 02. 23.
}

\begin{abstract}
Összefoglaló: Napjainkban több tudományos paradigma él egymás mellett és egymással vetélkedve a társadalomtudományokban, így a szociológiában is. Minden paradigma önálló ontológiával, episztemológiával és módszertani tudatossággal rendelkezik, amelyek jól elkülönülnek egymástól. Az egymás mellett létezés következtében azonban a különbségeken kívül egymáshoz való közeledés is érzékelhető. A kvalitatív szociológián belül a biográfiakutatásokban egyfajta kompromisszumkészség mutatkozik a nézőpontok között. A tanulmány első lépésként az „alapvető” paradigmák (pozitivizmus, posztpozitivizmus, kritikai elméletek, konstruktivizmus) rövid bemutatására vállalkozik, majd azok hatását vizsgálja a biográfiakutatásokra. Ezt követően a biográfiakutatók körében lezajlott paradigmavitát mutatja be, leírva, hogy bár „látszólag” nem közeledtek egymáshoz az álláspontok, mégis megfogalmazódott a különböző paradigmák közötti minimális konszenzus.
\end{abstract}

Kulcsszavak: paradigma, pozitivizmus, posztpozitivizmus, kritikai elméletek, konstruktivizmus, biográfiakutatás, narratíva

\section{Bevezetés}

A kvalitatív kutató sokszor teszi fel a kérdést, hogy a kutatási témájához összegyưjtött anyagokat hogyan dolgozza fel. A személyes dokumentumok, élettörténeti interjúk részleteit tényként vagy szövegként kezelje? Vajon a napjainkban divatossá váló narratívaelemzés az egyedül üdvözítő megoldás a kvalitatív források, köztük a biográfiák elemzésére, vagy más lehetőségekkel is érdemes számolni? Az összegyưjtött adataink felhasználása - mint Kuhn (2000) óta tudjuk - végső soron tudományfelfogásunktól függ. Különböző paradigmák állnak ma rendelkezésre, amelyek alakítják a valóságról vallott felfogásunkat, és ki-ki tudatosan vagy öntudatlanul ezek közül válogatva végzi a kutatásait. Forrásaink elemzésének ily módon a világgal kapcsolatos - többé vagy kevésbé tudatosított - ismeretelméleti feltevések jelentik az alapját, amelyek mélyén többnyire a valóságról alkotott, azaz ontológiai 
feltevések rejlenek, és amelyekből a kutatási módszerre, valamint az elemzésre, a kutatás eredményére nézve jelentős következmények fakadnak.

A kvalitatív kutatások terén napjainkban több paradigma vetélkedik egymással (Guba-Lincoln 1994, Denzin-Lincoln 2011, Denzin-Lincoln 2017). A témában sokat hivatkozott szerzőpáros, Guba és Lincoln 1994-ben még „csak” négy paradigma bemutatását tartotta fontosnak, de 2011-ben egy hasonló témájú tanulmányban kiegészítették azokat egy ötödikkel, amelyet részvételi (participatory) paradigmaként fordíthatunk. A szerzők a paradigmák mellett számos perspektívát is felsorakoztattak, ${ }^{2}$ jelezve a világról vallott felfogások egyre sokszínúbbé válását. A paradigmák és perspektívák számának gyarapodása mutatja, hogy a valóságról való gondolkodásunk folyamatosan differenciálódik. Denzin és Lincoln (2011: 95) szerint a kvalitatív kutató nem teheti meg, hogy ne legyen tisztában a különböző paradigmák értelmével és a közöttük lévő különbségekkel. Ugyanakkor azt is elengedhetetlennek tartják, hogy a kvalitatív kutató legyen képes a paradigmák közötti párbeszédre is (Lincoln et al. 2011: 97-128).

A tanulmányban röviden bemutatom a négy alapparadigmát, majd ezek megjelenését a kvalitatív társadalomtudományokban, különösen a biográfiakutatásokban. A biográfiakutatást jóformán minden társadalomtudomány használja, jelen dolgozatban azonban elsősorban a szociológiával való kapcsolatára fókuszálok. Más társtudományról csak akkor teszek említést, ha a téma kifejtéséhez szükségesnek látszik.

A tanulmány második felében megvizsgálom a paradigmák közötti verseny hatását a biográfiakutatásra, és rámutatok a közeledés folyamatára, amelyet többek között a paradigmák közötti verseny eredményének tekintek.

\section{A paradigmák közötti különbségek}

A társadalomtudományokban a sokáig uralkodó pozitivista paradigmát a hetvenes és a nyolcvanas években erős kritikák érték. Valójában paradigmaháborúról beszélhetünk, amely először a kvalitatív és a kvantitatív felfogások között dúlt, de hamarosan megjelent a különböző kvalitatív módszerek képviselői között is. ${ }^{3}$ (Denzin-Lincoln 2011: 1-21) A vitát a kvalitatív kutatók robbantották ki, mert kétségüket fejezték ki az objektív igazságba vetett hittel kapcsolatban, megkérdőjelezték a hatalmi pozíciót képviselő kutatói szerepet, és felmerült, ami korábban nem, hogy kinek az értelmezése kerül publikálásra a kutatás végén: a kutatóé vagy a kutatásban részt vevő alanyoké. Ezek a kérdések kiegészültek olyan módszertani problémákkal, mint az érvényesség, a megbízhatóság és az általánosíthatóság. A vitához kvantitatív és kvalitatív oldalról is sokan hozzászóltak, és a felvetésekre a kutatók saját paradigmájuk nevében válaszoltak. Milyen valóságfelfogásokat előfeltételeznek tehát a paradigmák?

2 A szerzők által említett perspektívák között szerepeltek többek között: a feminista elméletek, a kritikai faji és etnikai tanulmányok, a queerelmélet, a posztstrukturalista és a posztmodern tanulmányok stb.

3 A tanulmány további részében a paradigmavitát, a felfogások megkérdőjelezését a kvalitatív kutatók oldaláról tárgyalom, kvalitatív szerzők véleményét mutatom be és ütköztetem. Magam is kvalitatív és biográfiai módszerrel dolgozom. 
Az egyes paradigmák óhatatlanul az „eredeti”, pozitivista felfogáshoz képest fogalmazzák meg álláspontjukat. A pozitivizmus évszázados múltra tekint vissza, és a természettudományos logika szerint kezeli a társadalomtudományos kérdéseket. A felfogás ontológiáját naiv realizmusnak is szokás nevezni (Denzin-Lincoln 2011). Ebből a nézőpontból a körülöttünk lévő világ olyan adottság, amely megfelelő mérési technikával teljesen megismerhető. A pozitivizmus episztemológiája a kutatót a tudás birtokosának tekinti, és hisz abban, hogy az általa vizsgált emberek/csoportok életének rejtett szabályait tökéletesen megismerheti (Denzin-Lincoln 1998). Ennek feltétele a kutató módszertani felkészültsége, és ha ez adva van, akkor a társadalom tényszerű összefüggései megragadhatók.

A posztpozitivizmus már nagyobb alázattal gondolkodik a világ megismerhetőségéről. A két paradigma közötti kölcsönhatás vitathatatlan, és ma már senki sem tekinthető a szó eredeti értelmében pozitivista társadalomkutatónak. Ennek „köszönhetően” a szakmai vitákban a két paradigma között ritkán teszünk különbséget, és sokszor csak pozitivizmust vagy naturalizmust emlegetünk olyankor is, amikor posztpozitivista állásponttal találkozunk. E felfogás szerint a rajtunk kívül lévő objektív világot csak többé-kevésbé tudjuk megragadni. A pozitivizmussal ellentétben ez a felfogás lemond a teljes igazságról. Itt sem vitás a kutató aszimmetrikus helyzete: a kutatott társadalom, az emberek, kimondatlanul ugyan, de alárendelt szerepet játszanak. Ez mutatkozik meg például akkor, amikor a kutató a megkérdezett személytől mindent elfogad az adatgyüjtés során. Az adatok feldolgozásakor azonban mindent meg kell kérdőjeleznie ahhoz, hogy - hite szerint - eljuthasson egy lehetséges valósághoz. A kutató és a kutatott közötti viszony etikailag ambivalens, ez a paradigma azonban nem lát más megoldást a valóság megismerésére (GubaLincoln 1994, Denzin-Lincoln2011).

A posztpozitivista felfogáshoz képest a kritikai elméletek iskolája a történelmi „realizmus” talaján áll. Hangsúlyozza a társadalmakban mindig jelen lévő hatalmi helyzetet, amely még a demokráciát is meghatározza. A demokráciában a társadalmi viszonyokat politikai, gazdasági, etnikai és gender típusú egyenlőtlenségek strukturálják. Ezért a világ csak adott történelmi szituációk elemzésén keresztül érthető meg, amelyben le kell leplezni a mindenkori hatalmi viszonyokat. A kritikai felfogás episztemológiája és etikája nem fogadja el a kutató dominanciáját a kutatás során, ebben a felfogásban a kérdezők és a kérdezettek egyenrangú viszonyban állnak egymással. A kutatási eredmények nyíltan értékvezéreltek (szemben a pozitivista/ posztpozitivista felfogás neutralista önértelmezésével), amelyben a faji, a gender-, a queerelméletek szempontjai hangsúlyosan megjelennek (Denzin-Lincoln 1998). A kritikai társadalomtudomány a diskurzusok, a kulturális áruk és a kulturális szövegek hatalmi és ideológiai jellegének feltárására törekszik (Denzin 2017; Erikson 2011).

A fenti paradigmák mellett a nyolcvanas években megjelent a konstruktivista felfogás a társadalomtudományokban. Ez a paradigma alternatív világok egymás mellett élésében gondolkodik, amelyek ebben a megközelítésben társadalmi úton kon- 
struálódó valóságok. Mindebből következik a valóság többféle megközelíthetősége, amelyek akár konfliktusban is állhatnak egymással (Denzin-Lincoln 1998; Guba 1981; Sallay 2015: 9-22.) A konstruktivizmus szerint is egyenrangúnak számít a kutató és a kutatott személy. A konstruktivista felfogás szerint a kutatási eredményeket vissza kell juttatni a megkérdezetteknek, elsősorban ellenőrzés céljából, az eredmény érvényességének felmérésére. Ez a megoldás újdonságként jelent meg, a pozitivista és a posztpozitivista felfogás korábban nem követte ezt az eljárást, ma azonban egyre több követője van.

\section{Paradigmák közötti verseny}

Yvonna Lincoln (2009) a paradigmák közötti vetélkedést a nyolcvanas évek elejére teszi. Szerinte ezekben az években még egyedül a pozitivizmust tekintették tudományos módszernek, a többi felfogásnak meg kellett küzdenie az elfogadottságért. Lincoln későbbi szerzőtársa, Guba (1981) kijelentette, hogy nem várható el a kvalitatív módszerektől a pozitivista szemléletű általánosíthatóság, érvényesség és megbízhatóság feltételeinek teljesítése. A szerző akkoriban nem aratott osztatlan sikert sem a kvantitatív, sem a kvalitatív kutatók körében. Ezekben az években még a kvalitatív kutatók többsége is meg akart felelni a pozitivista felfogás követelményeinek.

Később azonban a kvalitatív kutatók a „szent hármas” (érvényesség, megbízhatóság és általánosítás) elvárásától határozottan elmozdultak. Fokozatosan megtörtént a pozitivista, másképpen fogalmazva a realista szemlélettől a konstruktivista és a posztmodern felfogások felé fordulás. Egyre kevesebben fogadták el a tiszta objektivitásra való törekvést, és felfogásukban a szubjektivitás elismerése nem jelentett egyet a tudománytalansággal. Tudományfilozófiai tendenciák mellett ezt a folyamatot gyakorlati okok is magyarázták. Többek között a kvalitatív kutatók meg akarták győzni az olvasókat és a kutatások finanszírozóit, hogy ők másképp kutatnak, mint kvantitatív társaik (Seale 2003). Ennek fényében többféle kvalitatív felfogás fogalmazódott meg a „szent hármas” kritériumát illetően. Voltak, akik egyszerűen ignorálták a pozitivista kritériumokat, mert azokat elnyomó kategóriáknak tekintették, amelyek megakadályozhatják a kvalitatív kutatás kreatív kibontakozását. Mások új tartalommal töltötték fel az érvényesség, a megbízhatóság és az általánosítás követelményeit. Új tartalomnak tekinthető például az a Steinar Kvale-féle javaslat, amely szerint az érvényesség elérhető úgy is, ha a kutató a saját álláspontját világossá teszi olvasója előtt, vagy azzal is, ha a saját állításait kritikusan megvizsgálja. A kutató ilyenkor az „ördög ügyvédje” szerepébe kerül, és megkérdőjelezi saját kijelentéseit. A megbízhatóság elérése kvalitatív módon úgy is történhet, ha a kutatás során folyamatosan ellenőrizzük, hogy arra a kérdésre kaptunk-e választ, amelyet a kutatás elején feltettünk. Ezt az „ellenőrzést” a megkérdezett személyek, az interjúk szövegei és a következtetések szempontjából folyamatosan el kell végezni. Az eredeti értelemben vett, statisztikai alapú általánosítás kérdéséről Kvale szerint egyszerűen 
le kell mondani, mert a kvalitatív kutatások nem tudnak, de nem is akarnak az egész társadalomra vonatkozó kijelentéseket tenni (Kvale 2007; Mason 2005).

Norman Denzin amerikai antropológus, a kvalitatív kutatások egyik tekintélyes képviselője ${ }^{4}$ sokat foglalkozik a paradigmák kérdésével, és az idők során saját álláspontja is módosult, feltehetően a viták hatására. Legutóbb (2017) a kritikai elméletek követőjeként definiálta önmagát. Elmondása szerint kutatói célja a demokráciában kiszolgáltatott társadalmi csoportok bemutatása, kutatási eredmények segítségével a társadalmi változás elősegítése. Ez az információ azért fontos a szerzőről, mert így érthetőbbé válik a paradigmákkal kapcsolatos véleménye.

Denzin és Lincoln (1998: 1-34.) a kilencvenes évek végén öt korszakot különböztetett meg egymástól a paradigmák vetélkedését ismertetve. Az első időszak a „tradicionális” nevet kapta, amelyben az uralkodó szemlélet a pozitivizmus volt, és 1900-tól 1950-ig tartott. A második a „modernista vagy aranykornak” számított, amikor színre lépett a posztpozitivizmus, de vele együtt színre lépett a hermeneutika, a strukturalizmus, a szemiotika, a fenomenológia és a kultúrakutatás is. Ez a fejlemény az 1950-1970-es évek közé tehető. Az alternatív megközelítések nemcsak fellendüléssel, hanem elbizonytalanodással is jártak a kvalitatív kutatók körében, amire a harmadik és a negyedik korszak elnevezései is utalnak. Ennek szellemében a harmadikat „átmeneti müfajok időszakának” nevezték, amellyel az 1970-1986 közötti időszakot jelölték. A negyedik szakaszt a „reprezentációs krízis” fémjelezte, és egy igen rövid időszakot, az 1986-1990 közötti éveket jelölték így. Ezt követte az ötödik korszak, amely az 1990-es évektől napjainkig tart, és amelyet egyszerűen csak „posztmodernként” emlegetnek (Denzin 2001: 324-330; Denzin-Lincoln 1998).

A korszakok megnevezéséből látható, hogy a második szakasz után minden paradigma egymás mellett él(t), nem kis fejtörést okozva a kvalitatív kutatásba újonnan érkezők számára. Az egymás mellett élés egyfelől provokálta a módszerek elsőbbségéről szóló vitát, másfelől a felfogások hatottak is egymásra (Creswell 2011).

\section{Paradigmák közötti minimumkonszenzus}

A paradigmaviták és az egymás mellett élés következményeként kialakult egyfajta minimális konszenzus, amelyet Denzin (2001) a következőképpen foglalt össze: 1. Minden paradigma valamilyen formában használja a pozitivista felfogást, mivel minden kutató érdekelt a valóság megismerésében, noha azt eltérő módon kezeli. 2. Mára általánossá vált a posztmodern filozófiákból fakadóan az alternatívákra való érzékenyítés. Vannak, akik ezt sokszínúségnek, vannak, akik relativizmusnak nevezik. Arról ma már senkit sem kell meggyőzni, hogy többféle nézőpont létezik. 3. Általánossá vált az egyéni megélések, az egyéni tapasztalatok felértékelődése a szociológiában, valamint az azok megértésére való törekvés. A szubjektív nézőpont

4 Denzin körülbelül kétévente 500-1000 oldalas kézikönyveket jelentet meg a témában jeles szerzők tanulmányaival. 
megismerése fontos lett. 4. Az etnometodológiai szemlélet terjedésével a mindennapokat vizsgáló kutatások természetessé váltak a szociológiában, a társadalomtörténetben, a környezetpszichológiában stb. (Bögre 2004; Majtényi 2015; Somogyi et al. 2018). 5. Clifford Geertz (1994) sűrű leírásra való buzdítása áttörte a diszciplínák és a paradigmák közötti kereteket, elfogadottá vált a kulturális antropológián kívül, a tágabban értelmezett kvalitatív kutatások körében is.

A paradigmák közötti közeledés szükségességét emlegette Lincoln is a kétezres évek elején, aki korábban a különbségek hangsúlyozásával szerzett magának elismertséget. Saját (konstruktivista és interpretív) felfogását védve, de az attól eltérőket is elfogadva, megpróbálta a konszenzus útját keresni. Szerinte az új paradigmák képviselőinek fel kellene hagyni az „ellenzéki” magatartással, mert nincs erre szükségük. Méltatta a módszertani sokszínűséget. Lincoln (2009) szerint a kritikai elméletek és a konstruktivizmus képviselői munkájuk során mély belátásokkal és ismeretekkel járultak hozzá a nyugati társadalom megismeréséhez. Ugyanakkor a szerző nemcsak a saját paradigmája eredményeit vette számításba, hanem a pozitivistákét/posztpozitivistákét is. A korábban használt érces hangvételhez képest új módon szólalt meg, amikor az utóbbiak munkáját házépítéshez hasonlította. Kiemelte, hogy a pozitivista/posztpozitivista kutató szisztematikusan gyújti a téglákat, és így összeáll egy ház az alapoktól kezdve a falakig, a tetőig bezárólag. Majd kijelentette, hogy az interpretív kutatások is tudáshoz vezetnek, csak másfajtához. A fenomenológiai értelmezés például egy jelenséget mélyen szeretne megérteni, előfeltevések nélkül. Békülékeny stílusban beszélt arról, hogy mindkét „hangra” szükség van ahhoz, hogy megértsük a világot (Lincoln 2009).

Lincoln példájából láthattuk, hogy a szerzők véleménye az idők során változhat, ahogyan ez Denzinnél is érzékelhető. Denzin (2017: 12)5 az utóbbi időben radikálisabban szólalt meg a témában, mintha lemondott volna a közeledésről. Határozottan kijelentette, hogy az objektivitás mítosza dekonstruálódott. A társadalomkutató a világot nem „Isten szemével” látja, és nincs abszolút érvényes módszer. A szerző szerint nincs objektív, politikailag neutrális kutató, aki a világot kívülről szemlélhetné, mert a kutatót megannyi biológiai, társadalmi, történelmi meghatározottság jellemzi. Ezenfelül mindenkinek megvan a saját története, és minden kutatás tükrözi a kutató saját álláspontját is. Megerősítette véleményét, miszerint a megfigyelések elméletvezéreltek, és határozott volt abban is, hogy vége a naiv realizmus korának. Felhívta a figyelmet a posztpozitivista felfogás újraéledésére, ezért azt kérte a kutatóktól, hogy mindenki a saját paradigmáján belül kérjen számon módszertani kritériumokat, és ne nyúljon át egyik paradigmából a másikba. A bemutatott érvek és ellenérvek jól tükrözik a paradigmák közötti vitákat, valamint a közeledésükre tett kísérleteket.

5 Denzin (2017) a kritikai elméletek nézőpontjai szerint szólal meg ebben a tanulmányában. 
A fentebb tárgyalt viták hatással voltak a biográfiára is. A továbbiakban a biográfiakutatás paradigmatikus változásait követem végig, amelyeknek iránya vitathatatlanul a pozitivista/posztpozitivista nézőponttól a konstruktivista álláspont felé mozdult el (Ross 2005).

\section{Pozitivizmus a biográfiakutatás hőskorában}

Martin Hammersley (2005) angol szociológus szerint a chicagói iskola első korszaka a biográfia szempontjából hőskornak számított. Az iskola jellemzői közé tartozott a szociológia és a szociálpszichológia összetartozása, akkoriban még nem váltak szét egymástól, mint napjainkban. Másik sajátosságként lehet említeni a kvalitatív és a kvantitatív módszerek, valamint a személyes dokumentumok kevert használatát. Például Ernest Burgess, az iskola egyik alapítója az élettörténetet kombinálta a statisztikai módszerrel, és ebben nem látott semmiféle problémát, mert egyenlő értékủnek tartotta a személyes dokumentumokat a statisztikai adatokkal (Hammersley 2005: 63-89). Ez a felfogás a kevert módszer elődjének tekinthető. Ebben az időben nem jelentett gondot a módszerek keverése, a felfogások paradigmatikus különbségei csak később kezdtek fontossá válni a kutatók számára ${ }^{6}$ (Koltai et al. 2015).

A korabeli chicagói iskola felfogása szerint a kutatók a személyes dokumentumokból az igaz „valóságot” tudták bemutatni. Akkoriban nem „gyötörték” a kutatókat a tények és a konstrukciók közötti különbségek: mindent, amit informátoraik és a források közöltek, tényként kezeltek. ${ }^{7}$

Az első klasszikus eredmények egyike a Thomas és Znaniecki szerzőpáros kutatása 1918-1920-ból, amelynek címe A lengyel paraszt Európában és Amerikában (Thomas-Znaniecki 2002). A szerzők a migráció hatását vizsgálták egyéni visszaemlékezések, levelezések alapján. A lengyel emigránsok helyzete problémát jelentett Európában és Amerikában is, de ez a kérdés a kötet megjelenése előtt nem kapott társadalmi nyilvánosságot. Az iparosodás hatásának feltárása személyes tapasztalatok kutatásával újdonságnak számított ebben a korban. A szerzők munkájukkal az emigráns lengyel parasztok dezintegrációs és integrációs folyamatait akarták bemutatni, és a személyes dokumentumokat tartották a legjobbnak a valóság kiderítésére.

A másik klasszikus élettörténeti kutatásnak Clifford R. Shaw Jack Roller (1930) címú munkája számít. Itt a főszereplő, Stanley egy húszéves rabló volt, akinek az életét mutatja be a szerző az alany szemszögéből. A kötet rendőrségi jelentéseket, pszichiátriai jegyzőkönyveket és az alany elbeszéléseit dolgozta fel egyes szám első személyben (Shaw 1966). Az említett személyes dokumentumok felhasználásával a szerző az alany nevében mondta el azt a történetet, amelyről azt feltételezte, hogy az „igaz” történet.

\footnotetext{
6 A tanulmány kereteit szétfeszítené a napjainkban újabb paradigmavitát kiváltó kevert (mixed) módszer terjedése. Magyarul a módszer támogatásáról lásd Király et al. (2014) tanulmányát.

7 A szerző egyik tanulmánya részletesebben foglalkozik ezzel (Bögre 2007).
} 
Fontos munkának számít még William Foote White tollából a Street Corner Society címú, 1943-ban megjelent könyv (Whyte 1993, 1999). Ez a mű a klasszikus antropológiai módszertan szerint íródott, a kutatási eredményt a szerző objektívnek tekintette. A kutatás Boston egyik utcájának olasz bevándorló munkásairól szól. A kutató kívülállóként érkezett a helyszínre, a közeget egy adatközlőn keresztül ismerte meg. Az adatközlő információkat osztott meg az utca életéről, ez alapján tárta fel a szerző a „valóságot”, azt, hogyan éltek az olasz bevándorlók Amerikában (Denzin 1996; Merrill-West 2009).

A chicagói iskola a klasszikus biográfiai hagyomány követésekor pozitivista álláspontot képviselt. A kutatók az alanyoktól kapott információkat objektívnek tekintették, az általuk leírt közeg kultúráját és viselkedésmódját úgy írták le, mint „igazságot.” Munkájuk sikeres és újszerú volt, kutatási témáikban azokat a társadalmi szereplőket szólaltatták meg, akik másként nem hallathatták volna a hangjukat. A társadalom láthatatlan világát és „underdog”-jait mutatták be (Kovács 2007: 269-270; Merrill-West 2009).

\section{A biográfiakutatás marginalizálódása}

A II. világháborút követően hanyatlott a chicagói iskolában a biográfiakutatás, Daniel Bertaux (2001) erősebb megfogalmazásában „eltűnt a szociológiából”. Ennek több oka lehetett. Az egyik, hogy a szociológia és a szociálpszichológia ekkor kezdett különválni egymástól, és a szociológia figyelme inkább a társadalmi struktúra kutatása felé fordult, és egyben a tudományág „professzionalizálódott.”

A másik ok a szerző szerint a módszertani szisztematikusság hiánya volt, amely a negyvenes évek közepéig még nem fejlődött ki a biográfián belül. Úgy látta, hogy erre először csak Lindesmith ${ }^{8}$ törekedett 1947-ben, ami azonban már késő volt. Ekkorra a szociológiába megérkezett a survey-kutatás, amely monopolhelyzetbe került. ${ }^{9}$ Nagy figyelmet és kutatási támogatást kapott ez a módszer, s a számszerűség nagy reményeket keltett a társadalom ,igaz megismerése” szempontjából. Ebben a folyamatban a személyes dokumentumok, az élettörténetek iránti érdeklődés háttérbe szorult (Chamberlayne et al. 2003; Merrill-West 2009). A marginalizálódás annak ellenére megtörtént, hogy Wright Mills (2009) és Peter Berger (2009), a szociológiai gondolkodás meghatározó alakjai továbbra is fontosnak tartották a biográfiai megközelítéseket, mivel felfogásuk szerint a társadalom makroszintje kifejeződik az emberek belső világában, a biográfia és a történelem keresztezi egymást.

A fentiek mellett a háború után maradt azért olyan szociológus, aki a chicagói iskola kvalitatív szellemében folytatta kutatásait, mint például Becker (Pessin 2017) vagy Goffman (1981). Másrészt a szociológiában lezajlott kvantitatív fordulat (amely

8 Alfred Ray Lindesmith (1905-1991) amerikai szociológus, aki szisztematikus módszert dolgozott ki a drogfüggés kutatásában. Herbert Blumer tanítványa volt.

9 Érdekes megjegyezni, hogy Daniel Bertaux is a survey-módszerrel kezdte szociológiai pályafutását, de úgy érezte, hogy ezzel nem tudja megismerni mélyebben a társadalmat. Vélhetően ezért fordult a figyelme a biográfia felé. 
megerősítette a pozitivista paradigmát) ellenére az amerikai antropológia továbbra is használta a biográfia módszerét. Erre a technikai fejlődés, mint például a magnószalag feltalálása, jó lehetőséget teremtett, és így olyan személlyel is lehetett interjút készíteni, aki nem tudta volna leírni az életét. Ebben a szellemben jelent meg Oscar Lewis Sánchez gyermekei (1968) címú múve, amely rendkívüli népszerúségre tett szert. ${ }^{10}$ A szerző egy mexikói szegény család történetét írta meg, amelyben a szereplők „saját szavaikkal” mondták el élettörténetüket. Meg kell jegyezni, a végső szöveget Lewis írta, a szövegben egyes szám első személyt használva. ${ }^{11}$ A szerző ezt a megoldást módszertani kísérletnek tekintette, amelyben korábbi családtörténeti kutatásainak módszerét meg akarta újítani (Bertaux 2001, 2003).

\section{A biográfiakutatás visszatérése}

Ross (2005) „paradicsomi állapot”-nak nevezte a biográfiakutatás visszatérését a hetvenes-nyolcvanas évek európai szociológiájába. A módszert használók körében még ekkor is a pozitivista álláspont uralkodott, amely szerint az élettörténeteket szó szerint vagy legalábbis többé-kevésbé igaznak gondolták. Az újrafelfedezők között találhatjuk az angol Paul Thompsont, a francia Daniel Bertaux-t és a német Martin Kohlit.

A biográfia visszatérését elősegítette a fentebb említett Lewis antropológiai kutatásának európai sikere. A kötet publikálásakor az olasz Franco Ferrarotti (1981) „belátta”, hogy a hétköznapi emberek történetét érdemes tanulmányozni. Ekkor, a nyolcvanas években Németországban és Franciaországban is a kutatások középpontjába került a hétköznapi emberek életének tanulmányozása, ami segítette a biográfiakutatás fellendülését.

A biográfiakutatás akkor indult el az intézményesülés felé, amikor 1978-ban Bertaux javaslatára egy biográfiai „ad hoc” csoportot hoztak létre a Nemzetközi Szociológiai Társaság (ISA) konferenciáján, amelyhez sokan csatlakoztak (Bertaux 2001; Chamberlayne et al. 2003). Ezt követte a „Biography and Society Research Committee" (továbbiakban BSRC) csoport 1984-es megalakítása az ISA keretein belül. Ez legitimizálta a műfajt a szociológiában (Apitzsch-Inowlocki 2000).

\section{Biográfiakutatás a paradigmák kereszttüzében}

A nyolcvanas-kilencvenes években a biográfiakutatást sem kerülte el a társadalomtudományokban akkoriban zajló paradigmatikus vita. A BSCR-csoport múködését is hamarosan szemléletmódokkal kapcsolatos viták tették próbára. A csoporton belül a francia/angol realista szemléletű szerzők felfogása összeütközésbe került a „német biográfiai iskola" képviselőivel, akik a narratív élettörténeti kutatás mellett kötele-

10 Ezt a könyvet még 1968-ban lefordították magyarra.

11 Lewishez hasonló módszerrel jelent meg hazánkban Csalog Zsolt Parasztregény című munkája (Csalog 1978). 
ződtek el (Kovács 2007;2012; Kovács-Vajda 2002; Vajda 2003). Az eltérő álláspontok mögött eltérô paradigmák álltak.

A francia/angol realista (pozitivista/posztpozitivista) szerzők „oral history”kutatásai, mint például Bertaux vagy a történész Thompson (1978) munkái jelentették az egyik irányt. Thompson The Voice of the Past című művét említhetjük, amelyhez 500 mélyinterjút használtak fel a kutatók. A sort Trevor Lummis Listening to History (1978) művével lehetne folytatni. A szerzők hangsúlyozták az „oral history”-élettörténetek eredetiségét, minőségi oldalát, és úgy vélték, hogy a vizsgált anyagok megfelelnek a reprezentativitás követelményének. A dokumentumok feldolgozása során mintavételi eljárásról beszéltek, és hittek abban, hogy elfogultságtól mentesen szólalhatnak meg. A megbízhatóság és az érvényesség szempontjait kiemelték a kutatási eredményeket illetően, ami egybecsengett a pozitivista/posztpozitivista állásponttal.

A Bertaux és Bertaux-Wiame szerzőpáros (1995) a francia pékek kulturális mintázatainak nemzedékeken keresztül zajló átadásáról írt máig is fontosnak tartott tanulmányt, amelynek módszertana posztpozitivistának mondható. Bertaux (2001, 2003) a biográfiai iskola „megmentése” érdekében tett lépései mellett oroszlánrészt vállalt a realista/posztpozitivista biográfia fősodorban tartásában is.

Munkájukat elismerés mellett sok kritika is érte. Lényegében két tűz közé szorultak, egyfelől kifogásolták, hogy nem kérdőjelezték meg az egyéni dokumentumok érvényességét (pozitivista oldalról jött támadás), másfelől támadás érte őket az oral history empiricizmusa miatt (konstruktivista oldalról jött támadás). Ez utóbbi szemlélet képviselői azt hiányolták, hogy nem foglalkoztak az interjúk szubjektív oldalával, a társadalom és a pszichológia hatásával az emlékekre.

A BSCR-csoportban a narrativitást képviselő „német biográfiai iskola”12 vitában állt Bertaux és Thomson körével. A hazai szociológiában a narratív felfogást képviselő Kovács Éva (2007: 272) ezt olyan folyamatnak írja le, amelyben „a biográfiakutatás, lassacskán elszakadva a történeti és emlékezetkutatásoktól, elméletileg inkább a filozófiában és az irodalomelméletben megújuló narratológiában fedezte fel kapcsolódási pontjait”. A narratológiának ez az irányzata az objektív hermeneutikán alapul, amelyre támaszkodva Schütze és Rosenthal kidolgozta a narratív élettörténeti interjúk készítésének módszerét. Az így készült interjúkat hermeneutikai esetrekonstukcióval dolgozzák fel a módszer követői (Denzin 1989; Kovács 2007; Vajda 2007). A hermeneutikai esetrekonstrukciót a hazai szociológiában, némi változtatással, először a Kovács-Vajda (2002)szerzőpáros használta, majd őket követték tanítványaik (Németh 2015).

12 A kifejezést annak ellenére használom, hogy vannak szerzők, akik szerint nem beszélhetünk egyértelműen „német” iskoláról (Apitzsch-Inowlocki 2000). 
A BSCR-csoportban 1997-ben kirobbant az említett két biográfiai iskola (angol/ francia versus német) között egy vita, amely publicitást kapott a Biography and Society Newsletter oldalain. E vita fontosságát bizonyítja a tanulmányok újraközlése, amelyet az angol iskola képviselője, Robert Miller (2005) nagyívü biográfiai szöveggyűjteményében jelentett meg. A vitában részt vevők saját felfogásukat védve és abból jottányit sem engedve nyilatkoztak meg. ${ }^{13}$

A polémiát a narratív felfogást képviselő Thierry Kochuyt (1997) kezdeményezte, amikor nevek említése nélkül kijelentette, hogy túl kellene lépni a pozitivista szemléletű biográfián. A módszer visszatérését a szociológiába fontosnak tartotta, ugyanakkor annak posztpozitivista felfogását idejétmúltnak tekintette. Feltette a kérdést, hogy az élettörténet az életet dokumentálja-e, vagy valami mást tesz. Felfogása szerint az élettörténetek fikciók, mert a múltban történt eseményeket az ember a jelenbeli állapota szerint tudja csak értelmezni. ${ }^{14}$ Ebben a szemléletben az élettörténeti kutatásoknak arra kellene fókuszálniuk, hogy felfejtsék, hogyan szerkeszti az egyén a történeteit, mert azzal a történetek jelentéseit értheti meg a kutató. Lényegében ne a pozitivista „mi történt?” kérdésével foglalkozzunk, mert azt úgysem tudhatjuk meg, hanem azzal, hogy a történetmondó miért mesél úgy, ahogyan. Ekkor közelebb juthatunk a személy identitásához, múltjának a jelenben megfogalmazott értelmezéséhez. Nem tehetünk mást, mert az élettörténetet mesélő egy olyan konstrukciót ad elő, amely a valóságban sohasem létezett. Mi ismerhető meg a narratív felfogásban? Az alany interpretációja, hogy az alany a vele történteket hogyan értelmezi ma.

Bertaux érezte magát megszólítva, mint „nagy öreg”, és hosszasan válaszolt az „ifjú titánnak”. Kifejtette: ha a narrativitás veszi át a vezető szerepet a biográfiában, azzal vége lesz a szociológiának. Ha egyetlenegy élettörténetet elemez a kutató, azzal a pszichoanalízis területére lép. Bertaux azzal érvelt, hogy a szociológiának a társadalmi valóságot kell megismernie, és az megfelelő módszerrel el is érhető. Ehhez interjúk sokaságát kell gyűjteni egy meghatározott társadalmi körből, majd az egyéni tapasztalatokat társadalmi és történelmi kontextusba kell helyezni, hogy a szubjektív megélés társadalmi perspektívába kerüljön. Kijelentette, hogy az alanyokat informátoroknak tekinti, akik el tudják mondani, hogy mi történt velük. Ők (tehát a posztpozitivisták) sem gondolják, hogy az alanyok az „igazságról” beszélnének. De ezen a „hibán” a sok interjú összehasonlításával túl lehet lépni, képessé válva a társadalmi mintázatok feltárására és a kollektív jelentések megértésére. Ezért látta úgy Bertaux, hogy az élettörténetekkel megismerhető a valóság, és az élet dokumentálható vele. Bertaux írására a Rosenthal és Rosenthal (2005) német szerzőpáros is válaszolt, akik Kochuyt és saját konstruktivista álláspontjukat fejtették ki. A vita végül Kochuyt végszavával zárult, amelyben „tehetséges veteránoknak” nevezte Bertaux-t és körét, de megerősítette, hogy felfogásuk túlhaladott.

13 A vitát és tanulságait részletesen egy önálló tanulmányban mutattam be (Bögre 2020).

14 Ezt a kérdést egyik korábbi tanulmányomban részletesebben tárgyaltam (Bögre 2007). 
Feltételezhetően az előbb összefoglalt érvek és ellenérvek segítettek a különböző vélemények közeledésében. A minimális kompromisszum egyik megfogalmazója a finn J. P. Ross volt. Ross tanulmányának első változatát (1994) még a fenti összecsapás előtt megírta, majd - feltehetően a Biography and Society szerkesztőségének kérésére - leporolta és újraközölte.

Ennek értelmében Ross (2005) szerint a paradigmák sokfélesége jótékony hatással volt a biográfia/önéletrajz módszerének tudatos átgondolására. Úgy vélte, a különböző paradigmák megjelenésének nyertese a narrativitás lett, annak álláspontja tudatosult a kutatókban. Ross szerint a biográfiakutatóknak tudniuk kell, hogy témájuk feldolgozása során nem magával a valósággal, hanem szöveggel dolgoznak (Pászka 2007, 2010). Kijelentette, hogy véget ért a biográfia számára az az illúzió, amely szerint az interjúalanyok az objektív igazságot közlik a kutatókkal. Ugyanakkor védelmébe vette a Bertaux-féle „féltve őrzött realitás” létezésének elvét, kijelentette, hogy mindenki számára létezik külső világ. Hangsúlyozta, hogy minden önéletrajzíró, minden élettörténetet mesélő személy annak tudatában ír és beszél, hogy létezik egy külső világ, amelyet mesélés közben tud megragadni.

Ross (2005: 170) továbbá megfogalmazta a paradigmák közötti minimális kompromisszumokat is. Ezek lényegében a pozitivista/posztpozitivista és a konstruktivista/narrativista álláspontok szempontjait közelítették egymáshoz. 1. Az élettörténetet társadalmi-kulturális kontextusba kell lehorgonyozni. 2. A hitelességgel kapcsolatban nem tudjuk biztosan, hogy hiteles-e, amit elmondott az alanyunk egy kutatásban, vagy sem. Ezért fontos, hogy megvizsgáljuk, kinek a szempontjából hiteles egy szöveg: a mesélő vagy a hallgató (kutató) szempontjából. 3. A hitelességet megerősiti a reflexitás. Különböző szinten szólalhat meg egy történet, illetve különböző nézőpontok vannak benne. Minél reflexívebb egy történet, annál több kontextus is van benne. 4. Hogy mi az igazság egy történetben, azt Ross szerint a referencialitás szempontjai alapján dönthetjük el. A kutató az állításokat vagy igaznak, vagy „csak” szimbolikusnak fogja fel.

\footnotetext{
Abstract: Nowadays, there is a diversity of parallel and competing scientific paradigms in social sciences, hence in sociology too. Each of these paradigms has its own distinct ontology, epistemology and a consciousness of methodology. Owing to their parallel existence, there is not only an emphasis on the differences but also a perceivable convergence of these paradigms. Without a dissolution of paradigms, there is a noticeable readiness to compromise within qualitative sociology, and within biographical research.

As a first step, this study undertakes to give a brief overview of some "basic" paradigms (positivism, postpositivism, critical theories, constructivism) which influence social sciences, sociology and biographies. Next, it will describe a debate of biography researchers on paradigms where there does not "appear" to have been any rapprochement. Yet, something did happen. In the light of the debate, a need for consensus among different paradigms has arisen in biographical research.

The author of this study aims to draw attention to this ambivalent situation where one can witness a competition between paradigms as well as their convergence.
} 
Keywords: paradigm, pozitivism, postpozitivism, critical theories, contructivism, biography method, narrative

\section{Irodalom}

Apitzsch, U. - Inowlocki, L. (2000): Biographical analysis: a 'German' school? In Chamberlayne, P. - Bornat, J. - Wengrafhe, T. (eds.): The Turn to Biographical Methods in Social Science. Comparative Issues and Examples. London-New York: Routledge, 53-70. https://doi.org/10.4324/9780203466049

Berger, P. (2009): Sociology as a Passion to Understand. In Joel, C. M. - Lee, G. V. (eds.): The Meaning of Sociology. A Reader. Upper Saddle River, New Jersey: Pearson Prentice Hall, 2-7.

Bertaux, D. (2001): Biography and Society. In Smelser, N. J. - Baltes, P. B. (eds.): International Encyclopedia of Social \& Behavioral Sciences. Amsterdam - Paris - New York-Oxford-Shannon-Syngapore-Tokyo: Elsevier, 1210-1213.

Bertaux, D. (2003): The Usefullness of Life Stories for a Realist and Meaningful Sociology. In Hunphrey, R. - Miller, R. - Zdravomyslova, E. (eds.): Biographical Research in Eastern Europe. Alternative lives and broken biographies. ChippenhamWiltshire: Ashgate, 39-52.

Bertaux, D. - Bertaux-Wiame, I. (1995): Artisanal Bakery in France: How it Lives and Why It Survives. In Glaser, B. (ed.): Grounded Theory 1984-1994. Vol. One. Mill Valley, CA: Sociology Press, 539-562.

Bögre Zs. (2004): Vallás és identitás. Élettörténetek a diktatúrában /1948-1964/. Pécs: Dialóg Campus.

Bögre Zs. (2007): Tények és/vagy konstrukciók? Múlt-Kor, Történelmi magazin. https://mult-kor.hu/20070816_tenyek_esvagy_konstrukciok?pIdx=3 (utolsó letöltés: 2021. 01. 10.)

Bögre Zs. (2020): Még egyszer: mire jó a biográfia? Tanulságok egy paradigma-vita kapcsán. Kultúra és Közösség, 3. 97-104. https://doi.org/10.35402/kek.2020.3.9

Chamberlayne, P. - Bornat, J. - Wengraf, T. (2003): The Biographical Turn. Introduction. In Chamberlayne, P. - Bornat, J. - Wengraf, T. (eds.): The Turn to Biographical Methods in Social Science. Comparative Issues and Eexamples. London-New York: Routledge, 1-33.

Creswell, J. W. (2011): Controversies in Mixed Methods Research. In Denzin, N. K. - Lincoln, Y. S. (eds.): The SAGE Handbook of Qualitative Research. Los Angeles London - New Delhi - Singapore - Washington DC: SAGE, 269-285.

Csalog Zs. (1978): Parasztregény. Budapest: Szépirodalmi Könyvkiadó.

Denzin, N. K. (1989): Interpretive Biography. Newbury Park: SAGE.

Denzin, N. K. (1996): The Facts and Fictions of Qulitative Inquiry. Qualitative Inquiry, 2(2): 230-241. 
Denzin, N. K. (2001): Reflexions and Reviews. The Seventh Moment: Qualitative Inquiry and the Practical of a More Radical Consumer Research. Journal of Consumer Research, 28 (September): 324-330.

Denzin, N. K. (2017): Critical Qualitative Inquiry. Qualitative Inquire, 23(1): 8-16.

Denzin, N. K. - Lincoln, Y. S. (1998): The Fifth Moment. In The Landscape of Qualitative Research: Theories and Issues. London: Sage Publications, 407-430.

Denzin, N. K. - Lincoln, Y. S. (2011): Paradigmatic Controversies, Contradictions, and Emerging Confluences, Revisited. In Lincoln, Y.S. - Lynham, S. A. - Guba, E.G. (eds.): The Sage Handbook of Qualitative Research. Los Angeles - London New Delhi - Singapure - Washington DC: SAGE, 97-128.

Denzin, N. K. - Lincoln, Y.S. (eds.) (2017): The SAGE Handbook of Qualitative Research. Los Angeles - London - New Delhi, Singapure - Washington DC: SAGE.

Erikson, F. (2011): A History of Qualitative Inquiry. in Social and Educational Research. In Denzin, N. K. - Lincoln, Y. S. (eds.): The Sage Handbook of Qualitative Research. Los Angeles - London - New Delhi - Singapure - Washington DC: SAGE, 43-61.

Ferrarotti, F. (1981): On the autonomy of the Biographical Method. In Bertaux, D. (ed.): Biography and Society. London - Beverly Hills: SAGE Publications, 19-27.

Geertz, C. (1994): Az értelmezés hatalma. Budapest: Századvég.

Goffman, E. (1981): A hétköznapi élet szociológiája. Budapest: Gondolat.

Guba, E. G. (1981): Criteria for Assessing the Trustworthiness of Naturalistic Inquiries. Educational Communication and Technology, 29(2): 75-91.

Guba, E. G. - Lincoln, Y. S. (1994): Competing paradigms in Qualitative Research. In Denzin, N. K. - Lincoln, Y. S. (eds.): Handbook of Qualitative Research. Thousand Oaks, CA: SAGE, 105-117.

Hammersley, M. (2005): The Dilemma of qualitative method. Herbert Blumer and the Chicago Tradition. London - New York: Routledge.

Király G. - Dén-Nagy I. - Géring Zs. - Nagy B. (2014): Kevert módszertani megközelítések. Elméleti és módszertani alapok. Kultúra és Közösség, V(II): 95-104.

Kochuyt, T. (1997): Could Objective Realities Tell Us a Story? Reply to Bertaux. Biography \& Society, December: 11-14.

Koltai J. - Sík E. - Simonovits B. (2015): A kvanti-kvali áldilemmán túl. Szociológia Szemle, 25(2): 31-49.

Kovács É. - Vajda J. (2002): Mutatkozás. Zsidó identitástörténetek. Budapest: Múlt és Jövő.

Kovács É. (2007): Interjús módszerek és technikák. In Kovács Éva (szerk.): Közösségtanulmány. Módszertani jegyzet. Néprajzi Múzeum - PTK BTK Kommunikáció és Médiatudományi Tanszék, 269-277.

Kovács É. (2012): Az emlékezés szociológiai elméletéhez. http://real.mtak.hu/62588/1/5kovacseva.pdf (utolsó letöltés: 2021. 01. 10.) https://doi.org/10.18030/socio.hu.2012.1.23 
Kuhn T. (2000): A tudományos forradalmak szerkezete. Budapest: Osiris.

Kvale, S. (2007): Doing Interviews. Los Angeles - London - New Delhi - Singapure Washington DC: SAGE.

Lewis, O. (1968): Sánchez gyermekei. Budapest: Európa.

Lincoln, Y. S. (2009): „What a Long, Strange Trip It's Been...”: Twenty-Five Years of Qualitative and New Paradigm Research. Qualitative Research, XX(X): 1-7. https://doi.org/10.1177/1077800409349754

Lincoln, Y. S. - Lynham, S. A. - Guba, E. G. (2011): Paradigmatic Controversies, Contradictions, and Emerging Confluences, Revisited. In Denzin, N. K. - Lincoln, Y. S. (eds.): The Sage Handbook of Qualitattve Research. Los Angeles - London - New Delhi - Singapure - Washington DC: SAGE, 97-128.

Lummis, T. (1978): Listening to History. The Authenticity the Oral Evidence. Oxford: Oxford University Press.

Majtényi Gy. (2015): „De elmehet a Kádár Jani a picsába!” Reziliencia az államszocializmusban. Replika, 5: 95-112.

Mason, J. (2005): Kvalitatív kutatás. Budapest: Jószöveg Műhely Kiadó.

Merrill, B. - West, L. (2009): Using Biographical Methods in Social Research. Los Angeles - London - New Delhi - Singapore - Washington DC: SAGE.

Mills, C. W. (2009): The Sociology Imagination. In Joel, M. C. - Lee, G. V. (eds.): The Meaning of Sociology. A Reader. Upper Saddle River - New Jersey: Pearson Prentice Hall, 8-12.

Német K. (2015): Tények, narratívumok és emlékezet: egy letűnt életvilág rekonstrukciójának lehetőségei. In Bodor P. (szerk.): Emlékezés, identitás, diskurzus. Budapest: L'Harmattan, 283-306.

Pászka I. (2007): Narratív történetformák. A megértő szociológia nézőpontjából. Szeged: Belvedere Meridionale.

Pászka, I. (2010): Sociology of Narrative Story Forms (Life Story, Autobiography). ClujNapoca: Presa Universita Clujeana.

Pessin, A. (2017): The Sociology of Howard S. Becker. Theory with a wide Horizon. Chicago-London: The University of Chicago Press.

Rosenthal, W. F. - Rosenthal, G. (2005): Daniel Bertaux's Complaints or Against False Dichotomies in Biographical Research. In Miller, R. (ed.) Biographical Research Methods. IV. London - Thousand Oaks - New Delhi: SAGE, 141-153.

Ross, J. P. (2005): Context, Authenticity, Referentiality, Reflexivity: Back to Basics in Autobiogrphy. In Miller, R. (ed.): Biographical Research Methods. IV. London Thousand Oaks - New Delhi: SAGE, 163-172.

Sallay V. (2015): Előszó a magyar kiadáshoz. In Corbin, J. - Strauss, A.: A kvalitatív kutatás alapjai. Budapest: L’Harmattan, 9-22.

Seale, C. (2003): Quality in Quantitative Research. In Lincoln, Y. S. - Denzin, N. K. (eds.): Turning Points in Qulitative Research. Tying Knots in a Handkerchief. Walnut Creek - Lanham - New York - Oxford: Altamira Press, 143-168. 
Shaw, C. R. (1966): The Jack-Roller: A Delinquent Boy's Own Story. Chicago-London: The University of Chicago Press.

Somogyi K. - Birtalan I. L. - Einspach-Tisza K. - Jantek Gy. - Kassai Sz. - Sebestyén E. - Dúll A. - Rácz J. (2018): Mi történik egy kvalitatív módszertan doktori szemináriumon? A GT. és az IPA-elemzés menete. Alkalmazott Pszichológia, 18(2): 105-127. https://doi.org/10.17627/ALKPSZICH.2018.2.105

Thomas, W. I. - Znaniecki, F. (2002): A lengyel paraszt Európában és Amerikában. Budapest: Új Mandátum.

Thomson, P. (1978): The Voice of The Past. Oral History. Oxford: Oxford Universtiy Press.

Vajda J. (2003): Az élettörténet szövegének szövete. JEL-KÉP. Kommunikáció, közvélemény, média, 22/1: 89-96.

Vajda, J. (2007): Two survivor cases: therapeutic effect as a side-product of the biographical narrative interview. Journal of Social Work Practice, 21/1: 89-102.

Whyte, W. F. (1993): Street Corner Society: The Social Structure Of An Italian Slum. London: University of Chicago Press.

Whyte, W. F. (1999): Utcasarki társadalom. Egy olasz szegénynegyed társadalomszerkezete. Budapest: Új Mandátum. 